\title{
A clawback compensation scheme and its effect on method options for earnings management
}

\author{
Ratna Candra Sari ${ }^{1 *}$, Mahfud Sholihin ${ }^{2}$ \\ ${ }^{1}$ Department of Accounting, Universitas Negeri Yogyakarta, Indonesia \\ ${ }^{2}$ Department of Accounting, Universitas Gadjah Mada, Yogyakarta, Indonesia \\ *Corresponding author e-mail: ratna_candrasari@uny.ac.id; ratnacandrasari08@gmail.com
}

A R T I C LE I N F O

Article history:

Available online

Keywords:

Clawback, accrual manipulation,

real activity manipulation,

earnings manipulation

DOI:

https://doi.org/10.20885/jaai.vol22. iss2.art4

\section{A B S T R A C T}

\section{Introduction}

Earnings have an important role in evaluating the performance of a company, thus encouraging some managers to engage in earnings management. Earnings management is the use of personal interests in making financial statements that can mislead financial report users (especially investors and creditors) about the economic performance of the company, or to influence contract results that depend on the accounting figures reported (Healy \& Wahlen, 1999). To prevent earnings management, many companies have recently adopted a clawback policy. Clawback is a provision that authorizes the board of directors to take back compensation that has been paid to the manager if evidence is found subsequently that managers engage in earnings management (Chan et al., 2015).

Several previous studies have examined the effectiveness of clawback (Chan et al., 2012; Dehaan, Hodge, \& Shevlin, 2013). Chan et al. (2012) and Dehaan, Hodge, and Shevlin (2013) found that after the adoption of clawbacks, financial statement misstatements decreased. However, more recent research has found that the clawback has unexpected consequences. Chan et al. (2015) shows that companies adopting clawbacks cause a change in earnings management methods from accrual manipulation to real activity manipulation. This is because real activity manipulation is not easily detected by regulators and auditors. Initially, the clawback model was designed by regulators to improve the quality of earnings or improve the integrity of financial statements. In fact, clawbacks cause managers to choose earnings management methods that are more difficult to detect by regulators and auditors (Chan et al., 2015).

Furthermore, most of the previous studies related to clawbacks were conducted using archival methods with samples of companies listed on the US Stock Exchange (Chan et al., 2012, 2015; Iskandar-Datta \& Jia, 2013). Therefore, it is important to test the effectiveness of clawback methods in countries with different culture, in this case one with high uncertainty avoidance and low individualism as found in Indonesia.

This research is important because (Schuler \& Rogovsky, 1998) states that national culture provides an important explanation of the variance of the effectiveness of compensation schemes. Han et al. (2010) found that the cultural dimensions of uncertainty avoidance and individualism can explain earnings management practices in certain countries. Countries with high uncertainty avoidance and low individualism (such as Indonesia) are found to have lower levels of earnings management than countries with low uncertainty avoidance and high individualism (such as the US). Therefore, this study aims to examine: firstly, whether the application of clawback compensation in Indonesia, a country with a high level of uncertainty and a low level of individualism, is effective in reducing the 
intention to engage in earnings management; secondly, whether the clawback causes a change in the choice of earnings management methods from accrual manipulation into real activity manipulation.

This research has important implications because it can provide recommendations to managers and regulators about the possibility of implementing a clawback compensation scheme in countries with cultures that are different from the countries that initiated the clawback. This research is different from previous research in several respects. Firstly, the research is conducted in countries with different cultural dimensions; the majority of previous research was conducted in the US, whereas this research was conducted in Indonesia. Secondly, most previous studies used secondary data (Chan et al., 2012, 2015; Iskandar-Datta \& Jia, 2013), while this study used primary data with an experimental approach. The experimental approach was chosen because in Indonesia the clawback compensation scheme is probably still rarely used so secondary data is not available.

This study found evidence that the application of a clawback can reduce a manager's intention to manipulate earnings, especially accrual manipulation. However, the clawback causes unexpected consequences whereby managers choose earnings management methods that are more difficult to detect by regulators and auditors. The systematic of writing this article is as follows. Firstly, there is an introduction. Seconly, there is a literature review and hypothesis formulation. Thirdly, the research method and the results of research are explained and discussed. This article ends with a conclusion.

\section{Literature Review}

\section{Clawback}

Clawback is a form of compensation system that was introduced in Section 304 of the Sarbanes-Oxley Act (SOX) in 2002. This clawback was introduced by the Securities and Exchange Commission (SEC) as an attempt to reclaim performance-based compensation paid to the CEOs and CFOs of public companies if evidence is found that the compensation is based on misstated financial statements.

Clawback features a penalty. Adoption of Clawback makes managers work harder to avoid any action that causes punishment (returning compensation that has been received). This is in accordance with Prospect Theory (Kahneman \& Tversky, 1979) which states that a person receives greater disutility from losses than the utility they receive from equal benefits. Therefore, individuals must work harder to avoid punishment than to get a bonus from the nominal money equivalent. Hannan (2005) found that individuals prefer to make greater efforts to avoid punishment than to receive bonuses from the nominal money equivalent. Empirically, it was found that companies that implement a clawback scheme have better financial reporting quality than companies that do not adopt clawback (Dehaan, Hodge, \& Shevlin, 2013).

\section{Earnings Management}

As mentioned in the introduction, earnings management is carried out by managers because there is a personal interest of managers in making financial reports that can mislead financial report users (especially investors and creditors) about the economic performance of companies to influence contract results that depend on reported accounting figures (Healy \& Wahlen, 1999). There are several methods of earnings management including: firstly, accrual manipulationis earnings management through discretionary accrual manipulation. This manipulation is used to reduce or increase reported profits by choosing accounting policies subjectively (Scott, 2009), for example managers choose accelerated depreciation methods compared to straight-line methods to reduce reported profits. Secondly, there is real activity manipulation which is defined as a deviation from the normal operating activities of the company motivated by the management's desire to provide stakeholders with the wrong understanding that certain financial reporting targets have been achieved through the company's normal operating activities (Roychowdhury, 2006). In other words, real earnings management involves efforts to change reported earnings by adjusting the time and scale of the underlying business activity, for example by reducing discretionary expenditures such as research and development costs, and sales, general and administrative costs.

Each method of earnings manipulation has costs and consequences. Accrual manipulation does not have a direct influence on cash flows, so it has only a small chance of damaging the value of the company (Badertscher, 2011). Manipulation of real activities is done by reducing discretionary costs so that this has an impact on cash flow. In the long run, real activity manipulation has a negative impact on optimal business activity and has the potential to damage the value of the company (Badertscher, 2011). Profit manipulation through real activity allows companies to increase short-term earnings, but this tendency will return to the level of earnings before earnings manipulation after three years (Chan et al., 2015). Even though it has an impact on cash flow, the risk of detecting activity manipulation is significantly lower than accrual manipulation because a decrease in discretionary costs, such as research and development costs, will not be the focus for inspections by auditors or regulators (Badertscher, 2011). 


\section{Clawback and Earnings Management}

Research related to the compensation system for earnings management has become a concern of researchers in Indonesia. Pujiati and Arfan (2013) found a negative effect of the bonus compensation system on earnings management, while Wijaya and Yulius (2014) stated that there was no influence. However, studies that examine the effectiveness of the clawback to reduce the level of earnings management have not received much attention. Previous research mostly used a sample of companies listed on the US Stock Exchange. After the adoption of the clawback, financial statement misstatements decreased (Chan et al., 2012). The implementation of the clawback increases market response and the motivation of investors to invest in the company (Iskandar-Datta \& Jia, 2013). With companies that adopt aclawback scheme, the quality of their financial statements increases compared to companies that do not adopt one (Dehaan, Hodge, \& Shevlin, 2013). Chan et al., (2015) found a decrease in accrual manipulation in US companies that adopted clawbacks. The hypothesis proposed is as follows:

$\mathrm{H}_{1}$ : After the clawback adoption, the intention to manipulate earnings decreases.

$\mathrm{H}_{2}$ : After the adoption of the clawback, the intention to do accrual manipulation decreases.

Denis (2012) found that investors and auditors believe there is an increase in the quality of financial statements after the application of clawbacks. Firstly, the application of clawbacks shows that the board of directors have a greater commitment to increased financial integrity. Secondly, there is excessive confidence on the part of auditors that companies that adopt the clawback provisions will issue more accurate reports thereby reducing the auditor's vigilance when examining the company's financial statements. This results in reducing the possibility that the auditor will find material misstatements. Therefore, voluntary adoption of clawback provisions, in fact, does not lead to more accurate financial reports (Denis, 2012). This is in accordance with the findings of the latest research which shows that the clawback has unexpected consequences. Chan et al. (2015) found that companies in the US that adopted clawbacks changed earnings management methods from accrual manipulation to real activity manipulation because real activity manipulation was a method of earnings manipulation that was difficult to detect by auditors and regulators (Graham, Harvey, \& Rajgopal, 2005).

The risk of detecting real activity manipulation is smaller than accrual manipulation (Badertscher, 2011). Manipulation of real activities is carried out and hidden in seemingly legal transactions, for example through decreasing discretionary costs such as R \& D costs, so that they are not the focus of audits and regulators. This results in a compensation clawback scheme that has an unexpected impact because it is able to reduce the use of earnings management methods that are easily detected (accrual manipulation) but increase the use of earnings manipulation methods that are difficult to detect namely real activity manipulation (Chan et al., 2015). Therefore, the research hypothesis proposed:

$\mathrm{H}_{3}$ : After the adoption of the clawback, the intention to do real activitity manipulation increases.

\section{Research Method}

\section{Experimental Design}

To test the hypothesis, a series of experimental sessions was carried out and each session lasted about 45 minutes. The experiment consisted of three parts. Firstly, the participants were told that they were in a bonus compensation scheme which was then changed to a clawback compensation scheme. Secondly, compensation for each participant is given according to the proposal that was chosen. Thirdly, participants answered questions to test manipulation and demographic characteristics.

The experimental design in this study is $2 \times 3$, within subject. In the scenario, participants are asked to take on the role of Chief Financial Officer (CFO) in hypothetical organizations and make decisions based on accounting policy proposals presented in the scenario. Participants are master level accounting students who have work experience in accounting departments. Having this work experience, participants are expected to have sufficient background knowledge to complete experimental tasks. Elliott et al. (2007) states that using student samples is a methodological choice that can be accepted if students have sufficient background knowledge to complete the task. Other reasons for using students as participants are: firstly, the purpose of this study is to test the theory. Because this theory must apply to all populations, so students can be used as samples. Secondly, students tend not to have limited time compared to practitioners, so it is more likely they will give their full attention (Jones, 2013). 


\section{Research Variables}

\section{Compensation scheme}

In this study, two compensation schemes used are the bonus scheme and clawback scheme. In the bonus scheme, if the company reaches its profit target, participants will get a bonus. The participants were asked to choose alternative proposals to reach the profit target. Each participant would get a bonus according to the chosen proposal (Table 1). In the experiment, the researcher invites the auditor to examine participants' answers and detect earnings manipulation.

If the participant is detected to be manipulating earnings, he will be given a reprimand by the auditor. In the clawback scheme, participants were told that the company had issued a new policy namely the clawback compensation scheme. In this scheme, if a participant is detected to be manipulating profits, the bonus that has been given must be returned. Participants are given the same case with the bonus scheme and are asked to choose available proposals to reach the profit target. The auditor tests participant's answers to detect earnings manipulation.

\section{Intention to Perform Accrual Manipulation and Real Activity Manipulation}

Each participant was given one scenario and asked to choose three proposals. This was a modified scenario from (Clikeman \& Henning, 2000). The first proposal is to measure the intention to engage in accrual manipulation. Participants evaluate proposals to delay recognition of maintenance costs until the following year. To ensure participants understand that this scenario is in accordance with accounting standards, information is provided: "Even though you realize this does not violate accounting standards, you are worried that this can affect the comparability of financial statements from one year to the next". The second proposal is to measure intention to manipulate real activities through cutting maintenance costs. To ensure that participants understand that the scenario complies with accounting standards and has a low risk of detection, information is provided: "Even though you realize this does not violate accounting standards and has a low risk of detection, you are worried that these short-term benefits will disappear afterwards". The third proposal is to measure intention not to do profit manipulation, even though the profit target is not achieved.

Participants answered questions related to their intention to make a proposal made in the scenario. The first question is: to what degree do you intend to engage in accrual earnings manipulation? This scale provides five options; 1 shows strongly disagree and 5 strongly agrees. Secondly, participants answer two questions related to their intentions regarding each proposal made in the scenario. One question uses a positive mode: "To what degree do you intend to do with the selected proposals?" Another question uses a negative mode: "To what degree do you intend not to do with the selected proposals?"

\section{Manipulation Check}

There are two questions for manipulation check. First, to ensure that participants understand the changes in the compensation scheme, the question posed is "Will there be a penalty, in the form of a return of the bonus, if earnings manipulation is detected?" Secondly, to ensure that participants understand accounting standards, the question posed is: "Are you sure the selected proposal does not violate accounting standards?"

\section{Financial incentives}

Table 1. The scenario used in Experiment

\begin{tabular}{llll}
\hline & & BONUS & CLAWBACK \\
\hline Proposal A & $\begin{array}{l}\text { Accrual manipulation } \\
\text { through cost delays }\end{array}$ & $\begin{array}{l}\text { The profit target is reached. The } \\
\text { returns } \\
\text { participant will receive compensation of } \\
\text { Rp150,000. }\end{array}$ & $\begin{array}{l}\text { If accrual manipulation is detected, } \\
\text { the Participant will return a bonus } \\
\text { of Rp. } 90,000\end{array}$ \\
Proposal B & $\begin{array}{l}\text { manipulation of real } \\
\text { activities through reducing } \\
\text { costs }\end{array}$ & $\begin{array}{l}\text { The profit target achieved. participants } \\
\text { will receive compensation of Rp100,000 }\end{array}$ & $\begin{array}{l}\text { If you detect manipulating real } \\
\text { activities, the Participant will be } \\
\text { asked to return a bonus deduction } \\
\text { of Rp. } 60,000\end{array}$ \\
Proposal C & $\begin{array}{l}\text { Not doing profit } \\
\text { manipulation }\end{array}$ & $\begin{array}{l}\text { The profit target is not reached. } \\
\text { participants will receive compensation of } \\
\text { IDR 25,000 }\end{array}$ & no bonus deductions \\
\end{tabular}


Participants receive compensation in the scenario depending on the proposal chosen and this compensation will be withdrawn if they are detected to be engaging in earnings management. The amount of bonus withdrawn depends on the proposal chosen. Detailed explanations are presented in Table 1.

\section{Results and Discussion}

The total number of participants in this study was 278 . However, 12 people did not pass the manipulation check. Thus, the data used were from 266 participants. Table 2 below shows descriptive statistics for the 266 participants. The average age of participants was 24.6 years. The average grade point average (GPA) was 3.41 and the average work experience was 1.97 years. Male participants comprised $43 \%$ while women participants comprised 57\%. Table 2 shows the demographic data. Results of a descriptive statistical test are shown in Table 3. Meanwhile, Table 4 shows the results of the Analysis of Variance.

Table 2. Demographic data

\begin{tabular}{lcccc}
\hline & Min & Max & Mean & Standard Deviation \\
\hline age & 22 & 36 & 24,69 & 2,75 \\
GPA & 3 & 4 & 3,41 & 0,49 \\
Work experience & 1 & 5 & 1,97 & 1,24 \\
\hline & $\mathrm{N}$ & $\%$ & & \\
man & 114 & $43 \%$ & & \\
woman & 152 & $57 \%$ & & \\
\hline
\end{tabular}

Table 3. Descriptive Statistics: Average intention to manipulate earnings (Standard Deviation)

\begin{tabular}{lcccc}
\hline \multirow{2}{*}{ compensation scheme } & In general & \multicolumn{3}{c}{ Based on the method } \\
\cline { 2 - 5 } & $\begin{array}{c}\text { Earnings } \\
\text { manipulation }\end{array}$ & $\begin{array}{c}\text { Accrual } \\
\text { manipulation }\end{array}$ & $\begin{array}{c}\text { Real activity } \\
\text { manipulation }\end{array}$ & \multirow{2}{*}{ No manipulation } \\
\hline Bonus & 2,32 & 2,45 & 3,00 & 3,39 \\
& $(0,98)$ & $(1,13)$ & $(1,14)$ & $(1,12)$ \\
Clawback & 1,98 & 1,87 & 3,58 & 3,71 \\
& $(0,90)$ & $(1,07)$ & $(1,26)$ & $(1,32)$ \\
\hline
\end{tabular}

Table 4. Results of Analysis of Variance Results

Effect of Compensation Schemes on Intention to do earnings Manipulation

\begin{tabular}{|c|c|c|c|c|c|c|c|c|}
\hline \multirow[b]{3}{*}{ Variabel } & \multirow{2}{*}{\multicolumn{2}{|c|}{$\begin{array}{c}\text { In general } \\
\text { Profit manipulation }\end{array}$}} & \multicolumn{6}{|c|}{ Based on the method } \\
\hline & & & \multicolumn{2}{|c|}{ Acrual manipulation } & \multicolumn{2}{|c|}{$\begin{array}{l}\text { Real activity } \\
\text { manipulation }\end{array}$} & \multicolumn{2}{|c|}{ No manipulation } \\
\hline & Statistics & $\begin{array}{c}\text { Two-tailed } \\
p \text {-value }\end{array}$ & Statistics & $\begin{array}{l}\text { Two-tailed } \\
p \text {-value }\end{array}$ & Statistics & $\begin{array}{l}\text { Two-tailed } \\
p \text {-value }\end{array}$ & Statistics & $\begin{array}{c}\text { Two-tailed } \\
p \text {-value }\end{array}$ \\
\hline Compensation Scheme & 13.75 & $<0.01$ & 4.26 & $<0.05$ & 9.86 & $<0.01$ & 2.29 & 0.13 \\
\hline
\end{tabular}

Table 4 shows that compensation schemes have a significant influence on intention to engage in earnings management. In the bonus compensation scheme, the intention to manipulate earnings is higher (2.32) compared to the clawback scheme $(1.98)(\mathrm{F}=13.75 ; \mathrm{p}<0,000)$. This finding supports $\mathrm{H} 1$ which posits that the implementation of the compensation scheme decreases the intention to manipulate earnings.

Hypothesis testing for $\mathrm{H} 2$ and $\mathrm{H} 3$ is done by testing the choice of profit manipulation method made by participants to reach the profit target. In the bonus scheme, the intention to use accrual manipulation was higher (2.45) than in the clawback scheme $(1.87)(\mathrm{F}=4.26, \mathrm{p}<0.05)$. Changes in the compensation scheme from bonus to clawback reduced the intention to engage in accrual manipulation, so $\mathrm{H} 2$ is supported.

By contrast, after applying the clawback, it turned out that the intention to engage in manipulation of real activities increased. The average score for the intention to engage in real activity manipulation in the bonus scheme is 3.00, increasing to 3.58 in the clawback scheme ( $\mathrm{F}=9.86, \mathrm{p}<0.01)$, so $\mathrm{H} 3$ is supported. Additional testing was carried out to test whether compensation schemes affect intention not to manipulate earnings. The results show that compensation schemes have no effect on the intention not to manipulate earnings. For the bonus scheme, the intention not to engage in profit manipulation (3.39) is lower than in the clawback compensation scheme (3.71), but the difference is not significant.

The results of this study indicate that the application of clawbacks decreases the intention to manipulate accruals, but the intention to manipulate real activities becomes higher. This is due to the fact that the use of real 
activity manipulation is a deviation from optimal operating activities, so it is not easily detected by auditors and regulators. This finding is consistent with Chan et al. (2015) that the use of real activity manipulation methods increased after companies adopted clawbacks, while the use of accrual manipulation declined.

\section{Conclusion}

The results of the study indicate that changes in the compensation scheme from a bonus scheme to a clawback scheme lead to unexpected consequences. Changes to the clawback scheme caused the intention to use real activity manipulation methods to increase, although the intention to use accrual manipulation declined. The results of this study have implications for the implementation of clawback in countries with high uncertainty avoidance and low individualism. In countries with these characteristics, an individual will be more careful when choosing earnings management methods to achieve targeted profits. After the implementation of the clawback, individuals continue to manipulate profits by using real activity manipulation methods because it is difficult to detect to avoid uncertainty in compensation received. Real activity manipulation is considered a less risky option than accrual management. Accrual manipulation tends to attract the attention of auditors and regulators. High accruals are more likely to be associated with restatement of financial statements, thus triggering clawbacks. The limitation of this study is the selection of the master program student's to be participants who, even though they have work experience, they are not managers who actually benefit from earnings management. Future research can add cultural variables at the individual level to examine the effectiveness of the provision of clawback.

\section{References}

Badertscher, B. A. (2011). Overvaluation and the choice of alternative earnings management mechanisms. The Accounting Review, 86(5), 1491-1518. https://doi.org/10.2308/accr-10092

Chan, L. H., Chen, K. C. W., Chen, T.-Y., \& Yu, Y. (2012). The effects of firm-initiated clawback provisions on earnings quality and auditor behavior. Journal of Accounting and Economics, 54(2-3), 180-196. https://doi.org/10.1016/J.JACCECO.2012.05.001

Chan, L. H., Chen, K. C. W., Chen, T. Y., \& Yu, Y. (2015). Substitution between real and accruals-based earnings management after voluntary adoption of compensation clawback provisions. The Accounting Review, 90(1), 147-174. https://doi.org/10.2308/accr-50862

Clikeman, P. M., \& Henning, S. L. (2000). The socialization of undergraduate accounting students. Issues in Accounting Education, 15(1), 1-17. https://doi.org/10.2308/iace.2000.15.1.1

Dehaan, E., Hodge, F., \& Shevlin, T. (2013). Does voluntary adoption of a clawback provision improve financial reporting quality? Contemporary Accounting Research, 30(3), 1027-1062. https://doi.org/10.1111/j.19113846.2012.01183.x

Denis, D. K. (2012). Mandatory clawback provisions, information disclosure, and the regulation of securities markets. Journal of Accounting and Economics, 54(2-3), 197-200. https://doi.org/10.1016/J.JACCECO.2012.07.002

Elliott, W. B., Hodge, F. D., Kennedy, J. J., \& Pronk, M. (2007). Are M.B.A. Students a good proxy for nonprofessional investors? The Accounting Review, 82(1), 139-168. https://doi.org/10.2308/accr.2007.82.1.139

Graham, J. R., Harvey, C. R., \& Rajgopal, S. (2005). The economic implications of corporate financial reporting. Journal of Accounting and Economics, 40(1-3), 3-73. https://doi.org/10.1016/J.JACCECO.2005.01.002

Han, S., Kang, T., Salter, S., \& Yoo, Y. K. (2010). A cross-country study on the effects of national culture on earnings management. Journal of International Business Studies, 41(1), 123-141. https://doi.org/10.1057/jibs.2008.78

Hannan, R. L. (2005). The combined effect of wages and firm profit on employee effort. The Accounting Review, 80(1), 167-188. https://doi.org/10.2308/accr.2005.80.1.167

Healy, P. M., \& Wahlen, J. M. (1999). A review of the earnings management literature and its implications for standard setting. Accounting Horizons, 13(4), 365-383. https://doi.org/10.2308/acch.1999.13.4.365

Iskandar-Datta, M., \& Jia, Y. (2013). Valuation consequences of clawback provisions. The Accounting Review, 88(1), 171-198. https://doi.org/10.2308/accr-50262

Jones, J. R. (2013). The role of individual attributes in earnings management intention decisions. Retrieved from https://rc.library.uta.edu/uta- 
ir/bitstream/handle/10106/23896/Jones_uta_2502D_12285.pdf?sequence=1\&isAllowed=y

Kahneman, D., \& Tversky, A. (1979). Prospect theory: an analysis of decision under risk (pp. 99-127). https://doi.org/10.1142/9789814417358_0006

Pujiati, E. J., \& Arfan, M. (2013). Struktur kepemilikan dan kompensasi bonus serta pengaruhnya terhadap manajemen laba pada perusahaan manufaktur yang terdaftar di bursa efek Indonesia tahun 2006-2010. Jurnal Telaah dan Riset Akuntansi, 6(2), 122-139.

Roychowdhury, S. (2006). Earnings management through real activities manipulation. Journal of Accounting and Economics, 42(3), 335-370. https://doi.org/10.1016/J.JACCECO.2006.01.002

Schuler, R. S., \& Rogovsky, N. (1998). Understanding compensation practice variations across firms: the impact of national culture. Journal of International Business Studies, 29(1), 159-177. https://doi.org/10.1057/palgrave.jibs.8490030

Scott, W. (2009). Financial accounting theory. (5th ed). Toronto, Ontario: Prentice Hall Canada.

Wijaya, V. A., \& Yulius, J. C. (2014). Pengaruh kompensasi bonus, leverage, dan pajak terhadap earning management pada perusahaan yang terdaftar di bursa efek Indonesia tahun 2009-2013. Tax \& Accounting Review, 4(1). 